\title{
Impact of Different Milk Yields of Cows on Milk Quality in Bohemian Spotted Cattle
}

\section{O. HANUŠ, J. FRELICH${ }^{1}$, L. JANU゚, A. MACEK ${ }^{2}$, I. ZAJÍČKOVÁ, V. GENČUROVÁ, R. JEDELSKÁ}

\author{
Research Institute for Cattle Breeding, Rapotín, Czech Republic \\ ${ }^{1}$ South Bohemia University, Agronomical Faculty, České Budějovice, Czech Republic \\ ${ }^{2}$ Agrovýzkum Rapotín, Czech Republic
}

Received February 23, 2006

Accepted October 11, 2007

\begin{abstract}
Hanuš O., J. Frelich, L. Janů, A. Macek, I. Zajíčková, V. Genčurová, R. Jedelská: Impact of Different Milk Yields of Cows on Milk Quality in Bohemian Spotted Cattle. Acta Vet. Brno 2007, 76: 563-571.

The milk yield (MY) is a significant economic and health factor. MY influences the health state of dairy cows, their reproduction performance, longevity and milk indicators (MIs). Differences within MIs between 2 higher (1; $8348 \mathrm{~kg}$ per lactation; 240 individual milk samples) and 2 lower yielding herds $(2 ; 7344 ; 239)$ of Bohemian Spotted dairy cows (B) were tested. Sampling was carried out during summer and winter feeding seasons. Lactation factors were well balanced. Group 1 was on a higher genetical level, had better nutrition and higher MY by $13.7 \%$ $(P<0.001)$. All herds were milked twice a day. Twenty-three MIs were examined and $39.1 \%$ (9 of $23 ; 30.4 \%$ it was formerly in Holstein $(\mathrm{H})$ with higher MY by $30 \%)$ were influenced $(P<$ 0.05 ) by relatively smaller difference in MY: fat; log somatic cell count; urea (U); acetone (AC); alcohol stability; time for enzymatic coagulation; whey volume; ratio of urea nitrogen in nonprotein nitrogen (URN); fat/protein content ratio. It shows a higher susceptibility of B cows to the impact of higher MY on lactation physiology than H. Most changes were in more important MIs, usually with higher differences compared with $\mathrm{H}$. The whole milk protein spectrum was not influenced $(P>0.05)$. The $U$ was higher $\left(5.707>4.365 \mathrm{mmol}^{-1} \mathrm{l}^{-1}\right)$ in group 1 , AC and URN as well $\left(0.0362>0.0238 \mathrm{mmol} \cdot \mathrm{l}^{-1}\right.$ and $\left.51.94>41.97 \%\right)$. It corresponds with nitrogen and energy metabolism.
\end{abstract}

Dairy cow, Bohemian Spotted cattle, milk yield, milk composition, milk properties, health status indicators

Decisions on many aspects of cattle keeping (breeding, feeding and milking technologies) are necessary for a good farmer strategy. Additional information about processing capacities or situation on the milk market are essential for competent decisions. These facts are of paramount importance for the milk yield (MY) and consequently its economic efficiency both under extensive and intensive production systems. High MY is preferred because of higher milk income. However, high MY is also under criticism because of the suspected negative impact on animal health, poor reproduction performance and propensity of cows to production disorders and reduced longevity. A poor reproduction performance and longevity were found under a long protein over-loading of dairy cows metabolism by nutrition to ensure high MY. This was connected with high urea concentrations in their body fluids (Piatkowski et al. 1981; Butler et al. 1996; Ropstad and Refsdal 1987; Ríha and Hanuš 1999ab; Hanuš et al. 2001). Despite this fact, most breeding programmes focus on the genetical improvement (GI) of MY beside the desirable increase of milk components, particularly protein content. The average MY has increased by more than $40 \%$ in the Czech Republic during the last fifteen years. The MY efficiency depends on numerous external and internal factors. The question is, what MY level is still efficient? There is no general answer to this question. The MY is increased by GI in most dairy herds and somewhere also due to 
more frequent daily milking. Improved dairy cow nutrition is another factor. The MY level and its lactation physiology could among other things influence the milk composition and properties. Breed changes in the Czech dairy cow population were mentioned (Kvapilík and Střeleček 2003; Kvapilík, Pytloun, Bucek et al. 2002, 2003, 2004; Kučera and Král 2004; Bucek et al. 2004) including its reduction and MY increase. Simultaneously, reproduction performance and longevity of dairy cows deteriorated markedly. Therefore the strategy of the genetically improved longevity has been supported recently. The Bohemian Spotted cattle (B) dairy cow population has been reduced recently, mostly because of the poor situation on the milk or beef market. The average MY increased by $1850 \mathrm{~kg}$ (from 4011 to $5861 \mathrm{~kg}$ ) from 1993 to $2004(46.1 \%)$. A risk of increase of the production disorder was mentioned simultaneously. The necessity of studies on the impacts of the MY increase on cows, their lactation physiology, health status and milk quality is generally on the rise (Sawa and Piwczynski 2002; Ayadi et al. 2003; Remond et al. 2004; Junqueira et al. 2005).

The aim of this paper was to estimate the impact of higher MY on the larger scale of the milk components and properties (to a larger extent than Suchánek and Hanuš (1997) and Kučera and Král (2004)) under current conditions and development degree of the B breed. Especially influences on the milk indicator (MI) changes with importance for processing industry and also on the values of MIs for production disorders of dairy cows and generally for lactacion physiology are taken into account. Only changes of the routine MIs (such as fat, protein, lactose, solids non-fat and urea contents and somatic cell counts) are usually known in connection with MY. The reasons for the investigation are mentioned in the previous work ( $\mathrm{J}$ a n $\mathrm{̊}$ et al. 2007). This could provide information about possible results of GI programme of dairy herds regarding MIs and their importance for the milk food chain.

\section{Materials and Methods}

During 3 years individual milk samples (MSs) were collected from 4 herds of B cows. Higher MY animals were randomly chosen with respect to the number and stage of lactation in accordance with the real profile of the herd. MSs were obtained regularly during summer (August, September) and winter (February, March) seasons. All dairy cows were fed also by addition of concentrate mixture in accordance with MY and standard demands. The feeding rations consisted of the following roughage: alfalfa silage + maize silage, whole year (herd 1); grass silage + GPS (silage) from cereals (or maize silage or sugar beet chips) in winter and a similar mixture with grass pasture in summer (2); clover and grass silage + maize silage, the whole year (3); grass silage + maize silage, the whole year (4). Nutrition and feeding were not the same among the herds. This was one of the reasons why the average MYs of herds were different. Another reason for the higher MYs in group 1 (herds 1 and 2) in comparison with average MY group 2 (3 and 4) was a higher degree of the GI for MY. The herds were kept in the following altitudes: 1, $225 \mathrm{~m} ; 2,600 \mathrm{~m} ; 3,605 \mathrm{~m} ; 4,570 \mathrm{~m}$.

The analyses were in accordance with the previous paper (Janů et al. 2007). The investigation was aimed at MIs: DMY daily milk yield ( $\mathrm{kg}$ of milk/day); FAT fat $\left(\mathrm{g} \cdot 100 \mathrm{~g}^{-1}\right)$; LAC lactose (monohydrate; $\left.\mathrm{g} \cdot 100 \mathrm{~g}{ }^{-1}\right)$; SNF solids non fat $\left(\mathrm{g} \cdot 100 \mathrm{~g}^{-1}\right)$; SCC somatic cell count $\left(10^{3} \cdot \mathrm{ml}^{-1}\right)$; U urea $\left(\mathrm{mmol} \cdot \mathrm{l}^{-1}\right)$; AC acetone $\left(\mathrm{mmol} \cdot \mathrm{l}^{-1}\right)$; $\mathrm{pH}$ acidity; $\mathrm{C}$ electrical conductivity $\left(\mathrm{mS} \cdot \mathrm{cm}^{-1}\right)$; $\mathrm{AL}$ alcohol stability (in $\mathrm{ml}$ ); $\mathrm{SH}$ titratable acidity (in $\mathrm{ml} 0.25 \mathrm{~mol} \cdot 1^{-1} \mathrm{NaOH}$ solution, used to titration of $100 \mathrm{ml}$ of milk); TEC time for enzymatic coagulation (in seconds); RCQ subjective estimation of the rennet curds quality (in classes); RCF rennet curds firmness (in mm); WV whey volume (in

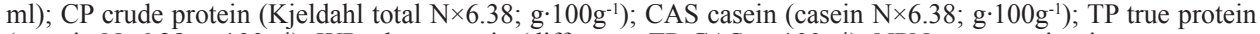

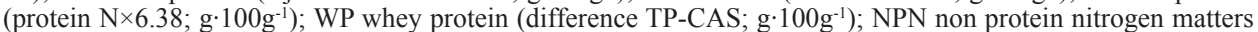
(CP-TP nitrogen $\left.\times 6.38 ; \mathrm{g} \cdot 100 \mathrm{~g}^{-1}\right)$; URN urea nitrogen/non protein nitrogen ratio $(\%)$; $\mathrm{F} / \mathrm{CP}$ fat/crude protein ratio. The casein numbers as possible indexes of cheesemaking yield of milk on the basis of CP and TP were in \% (CN-CP, CN-TP). The MI differences between group averages 1 and 2 were investigated ( 240 and 239 individual MSs). The groups were well-balanced regarding the relevant seasonal influences and in terms of lactation stage and number. Statistical characteristics were calculated: arithmetical mean (x), geometrical mean (xg), standard deviation (sd), variation coefficient (vx, \%), $t$-values for significance assessing of the differences (Excel). The $\mathrm{SCC}$ (in $10^{3} \cdot \mathrm{ml}^{-1}$ ) and AC (in original $\mathrm{mg} \cdot \mathrm{l}^{-1}$ ) were transformed on logarithmic scale to obtain the $\mathrm{xg}$ bacause the $\mathrm{x}$ is not proper characteristic of frequency distribution of their original values (Ali and Shook 1980; Shook 1982; Hanuš et al. 1995ab). The data files are presented in figures by the box graphs with the following construction rules: the file median (the central short horizontal line); the top edge of $1^{\text {st }}$ and $3^{\text {rd }}$ quartile (the tetragon); the variation range as difference between maximum and minimum (the vertical line). 


\section{Results and Discussion}

Higher daily MY of group 1 corresponded with average MY in the standard lactation (305 days) $8348 \mathrm{~kg}$ in contrast to $7344 \mathrm{~kg}$ in group 2 (Table 1). The average daily MY in group 1 was higher than in group 2 by $13.7 \%(3.29 \mathrm{~kg}$ where $27.37>24.08 \mathrm{~kg})$. The difference was marked, significant $(P<0.001$; Table 1 and Fig. 1, DMY), but not too high. There were no significant $(P>0.05)$ differences in consideration of the lactation stage (SL, group one $146.1 \pm 75.4$ and group two $143.8 \pm 73.1$ days in milk) and lactation number (NL, group one $2.6 \pm 1.5$ and group two $2.5 \pm 1.5$ lactations). This investigation was probably not influenced by the interferential effects of the lactation stage and number.

Table 1. Significance of the differences in milk chemical components, health indicators and physical and technological properties between groups of B cows with higher (1) and lower (2) MY.

\begin{tabular}{|c|c|c|c|c|c|c|c|c|}
\hline \multirow{4}{*}{$\begin{array}{l}\text { nL } \\
\mathrm{n}\end{array}$} & \multicolumn{3}{|c|}{1} & \multicolumn{3}{|c|}{2} & \multirow{2}{*}{$t$} & \multirow{2}{*}{ sign. } \\
\hline & $\mathrm{x} \pm \mathrm{sd}$ & $\mathrm{vx} \%$ & $\mathrm{xg}$ & $\mathrm{x} \pm \mathrm{sd}$ & vx \% & $\mathrm{xg}$ & & \\
\hline & \multicolumn{3}{|c|}{240} & \multicolumn{3}{|c|}{239} & & \\
\hline & $2.6 \pm 1.472$ & 56.62 & & $2.54 \pm 1.483$ & 58.39 & & 0.44 & ns \\
\hline SL & $146.08 \pm 75.37$ & 51.60 & & $143.77 \pm 73.05$ & 50.81 & & 0.34 & ns \\
\hline DMY & $27.37 \pm 8.021$ & 29.31 & & $24.08 \pm 7.71$ & 32.02 & & 4.57 & $* * *$ \\
\hline FAT & $3.85 \pm 0.892$ & 23.16 & & $4.04 \pm 0.880$ & 21.81 & & 2.28 & $*$ \\
\hline LAC & $4.97 \pm 0.197$ & 3.96 & & $4.94 \pm 0.215$ & 4.35 & & 1.59 & $\mathrm{~ns}$ \\
\hline SNF & $8.93 \pm 0.35$ & 3.92 & & $8.88 \pm 0.349$ & 3.93 & & 1.56 & ns \\
\hline SCC & $193.87 \pm 615.163$ & 317.31 & & $174.92 \pm 408.764$ & 233.69 & & 0.40 & ns \\
\hline $\log \mathrm{SCC}$ & $1.7382 \pm 0.5539$ & 31.87 & 55 & $1.8524 \pm 0.5281$ & 28.51 & 71 & 2.30 & $*$ \\
\hline $\mathrm{U}$ & $5.707 \pm 2.212$ & 38.75 & & $4.365 \pm 1.469$ & 33.65 & & 7.80 & $* * *$ \\
\hline $\mathrm{AC}$ & $0.0499 \pm 0.0405$ & 81.21 & & $0.0401 \pm 0.0476$ & 118.54 & & 2.43 & $*$ \\
\hline $\log \mathrm{AC}$ & $0.3224 \pm 0.3872$ & 120.10 & 0.0362 & $0.1400 \pm 0.4935$ & 352.50 & 0.0238 & 4.49 & $* * *$ \\
\hline $\mathrm{pH}$ & $6.72 \pm 0.127$ & 1.89 & & $6.72 \pm 0.131$ & 1.95 & & 0.00 & ns \\
\hline $\mathrm{C}$ & $4.28 \pm 0.492$ & 11.50 & & $4.25 \pm 0.465$ & 10.94 & & 0.68 & ns \\
\hline $\mathrm{AL}$ & $1.3 \pm 0.787$ & 60.54 & & $1.61 \pm 0.993$ & 61.68 & & 3.78 & $* * *$ \\
\hline $\mathrm{SH}$ & $7.62 \pm 0.864$ & 11.34 & & $7.53 \pm 1.001$ & 13.29 & & 1.05 & ns \\
\hline TEC & $102.81 \pm 38.759$ & 37.70 & & $115.53 \pm 54.74$ & 47.38 & & 2.93 & $* *$ \\
\hline RCQ & $2.41 \pm 0.989$ & 41.04 & & $2.44 \pm 0.994$ & 40.74 & & 0.33 & ns \\
\hline $\mathrm{RCF}$ & $15.98 \pm 3.443$ & 21.55 & & $16.31 \pm 3.077$ & 18.87 & & 1.10 & ns \\
\hline WV & $35.26 \pm 3.137$ & 8.90 & & $34.64 \pm 3.359$ & 9.70 & & 2.08 & $*$ \\
\hline $\mathrm{CP}$ & $3.45 \pm 0.335$ & 9.71 & & $3.41 \pm 0.316$ & 9.27 & & 1.34 & ns \\
\hline CAS & $2.74 \pm 0.288$ & 10.51 & & $2.71 \pm 0.281$ & 10.37 & & 1.15 & $\mathrm{~ns}$ \\
\hline TP & $3.25 \pm 0.317$ & 9.75 & & $3.22 \pm 0.303$ & 9.41 & & 1.06 & ns \\
\hline WP & $0.51 \pm 0.094$ & 18.43 & & $0.5 \pm 0.097$ & 19.40 & & 1.14 & ns \\
\hline NPN & $0.20 \pm 0.06$ & 30.00 & & $0.19 \pm 0.064$ & 33.68 & & 1.76 & ns \\
\hline URN & $51.94 \pm 17.717$ & 34.11 & & $41.97 \pm 15.108$ & 36.00 & & 6.61 & $* * *$ \\
\hline $\mathrm{F} / \mathrm{CP}$ & $1.12 \pm 0.248$ & 22.17 & & $1.18 \pm 0.249$ & 21.07 & & 2.99 & $* *$ \\
\hline $\mathrm{CN}-\mathrm{CP}$ & $79.37 \pm 2.933$ & 3.70 & & $79.5 \pm 2.932$ & 3.69 & & 0.48 & ns \\
\hline CN-TP & $84.17 \pm 2.617$ & 3.11 & & $84.28 \pm 2.802$ & 3.33 & & 0.44 & ns \\
\hline
\end{tabular}

Statistical significance of the difference: $\mathrm{ns}=P>0.05 ; *=P \leq 0.05 ; * *=P \leq 0.01 ; * * *=P \leq 0.001$;

$\mathrm{n}=$ number of incidents; $\mathrm{x} \pm \mathrm{sd}=$ arithmetic mean \pm standard deviation; $\mathrm{xg}=$ geometric mean

$t=$ test criterion of $t$-test; sign. = significance of the difference.

NL mumber of lactations; SL stage of lactation; DMY daily milk yield; FAT fat; LAC lactose; SNF solids non fat; SCC somatic cell count; U urea; AC acetone; $\mathrm{pH}$ acidity; $\mathrm{C}$ electrical conductivity; AL alcohol stability; $\mathrm{SH}$ titratable acidity; TEC time for enzymatic coagulation; RCQ rennet curd quality; RCF rennet curd firmness; WV whey volume; CP crude protein; CAS casein; TP true protein; WP whey protein; NPN non protein nitrogen; URN urea nitrogen/non protein nitrogen ratio; $\mathrm{F} / \mathrm{CP}$ fat/crude protein ratio; $\mathrm{CN}-\mathrm{CP}$ and $\mathrm{CN}-\mathrm{TP}$ casein numbers. 
The higher MY reached in group 1 by the higher cow breeding degree within the B breed and due to a more effective nutrition and feeding, influenced significantly $(P \leq 0.05, P \leq$ 0.01 and $P \leq 0.001$; Table 1) the following MIs: FAT; log SCC; U; $\log$ AC; AL; TEC; WV; URN; F/CP (Fig. 1). There are nine significantly affected MIs $(39.1 \%$ of the investigated MIs). Previously (Janů et al. 2007) the identical ratio was $30.4 \%$ in the Holstein (H); despite the fact that the stated significant difference between the compared average MYs was much higher than in this work $(30.0>13.7 \%)$. That is why the $\mathrm{B}$ cows were probably more susceptible to the influence of MY on MIs. The B breed file of the influenced MIs consisted of more important markers in terms of technological, compositional and health point of view as compared with $\mathrm{H}$. The other fifteen investigated MIs were influenced nonsignificantly $(P>0.05$; Table 1$)$. The most important MIs were not significantly negatively influenced due to the breeding programme and other associated farmer factors (such as efficiency of nutrition and feeding in terms of the meeting of dairy cow genetical capacity) which cause a higher MY in the B breed under the current conditions.

Considering the composition MIs only the fat was influenced (Table 1 and Fig. 1, FAT; $P<0.05)$ and dairy cows with higher MY had lower fat content $(3.85<4.04 \%)$. It could be caused by a negative energy balance in the higher yielding cows. An occurrence of the lipomobilisation effect was not observed in milk in group 1, nevertheless the fat variability was higher in the same group $(23.2>21.8 \%)$. This fact could be seen as a confirmation of the hypothesis mentioned previously. A lower fat content was observed, similarly as in other major and minor milk components, in breeds with higher MY (Suchánek and Gajdůšek 1991; Hanuš and Foltys 1991) and a similar effect probably holds true within one breed. The same constellation was observed previously (Janů et al. 2007) in H cows, however, the impact was evaluated as non-significant $(P>0.05)$. Regarding the general principles of energy metabolism (Andersson and Lundström 1984ab; Andersson 1984, 1985; Andersson and Emanuelson 1985; Gravert et al. 1986; Diekmann 1987; Jagoš et al. 1991; Gustafsson and Emanuelson 1993; Illek and Pechová 1997; Geishauser et al. 1997, 1998; Pechová et al. 2000; Kirchnerová et al. 2001; Chládek et al. 2002), we expected a significant effect with the milk fat content depression in the dairy cows with higher MY. It was confirmed in the B cows. Surprisingly, the milk CP, TP and casein contents were not significantly affected by the MY level of the cows in this case. It was similar in comparison with the previous result in H cows (Janů et al. 2007).

The group of health status MIs was affected by MYs as follows: log SCC $(P<0.05)$; $\mathrm{U}(P<0.001)$; AC and $\log \mathrm{AC}(P<0.05$ and $P<0.001)$; URN $(P<0.001) ; \mathrm{F} / \mathrm{CP}$ ratio $(P$ $<0.01$; all Table 1 and Fig. 1$)$. The $\log$ SCC was significantly lower in cows with higher MY (Fig. 1; comparison of xg $55<7110^{3} \cdot \mathrm{ml}^{-1}$ ) but with higher variability of the original SCC values $(317>233 \%$ ), which caused an opposite trend (comparison of $\mathrm{x} 194>175$ $\left.10^{3} \cdot \mathrm{ml}^{-1}\right)$ and non-significance of the difference $(P>0.05)$ between mean values of the original data. Therefore it is not possible to emphasise higher or average MYs as incidental sources of higher or lower occurrence of the milk secretion disorders (as e.g. Foltys and Kirchnerová (2001) found the fed organic selenium as a source of significant SCC decrease) or subclinical mastitis under practical conditions. Both mentioned differences are relatively not so high and they are negligible in practice, independently of their statistical significance.

In consideration of $U$ difference (Table 1; Fig. 1; which is equal to $1.342 \mathrm{mmol} \cdot \mathrm{l}^{-1}$, where $\left.5.707>4.365 \mathrm{mmol} \cdot \mathrm{l}^{-1}\right)$, this is marked and approximately twice as high than observed in the $\mathrm{H}$ cows $\left(0.7 \mathrm{mmol} \cdot \mathrm{l}^{-1}\right.$ in the same trend $4.265>3.565 \mathrm{mmol} \cdot \mathrm{l}^{-1}$, but with a markedly lower both $U$ and in particular with higher mean daily MYs in both groups $33.7>26.0 \mathrm{~kg}$ ) under relatively similar circumstances (Janů et al. 2007). The averages had a little different variability $(38.8>33.7 \%)$ in this investigation and higher $U$ values were stated in cows with higher MYs in both of the cases of the investigations (in B here and in H cows previously, 
Janů et al. 2007). This finding is in consistency with current knowledge of nitrogen matter metabolism in dairy cows (Kirchgessner et al. 1985, 1986; Hanuš et al. 1993; Illek and Pechová 1997; Pechová et al. 2000; Johnson and Young 2003; Kučera 2003; Jílek et al. 2006; Zhai et al. 2006; Strusiňska et al. 2006) that animals with higher MY very often suffer from a higher nitrogen over-loading of their internal body environment. This state could affect their pregnancy and longevity (Piatkowski et al. 1981; Butler et al. 1996; Ropstad and Refsdal 1987; Ř́ha and Hanuš 1999ab; Hanuš et al. 2001) in a negative way. Part of the metabolic energy sources is regularly consumed for ammonia detoxication to $\mathrm{U}$ in the liver. A relationship between milk $\mathrm{U}$ and MY of H cows was found by Kučera (2003), too. It was a positive relationship and a certain stagnation of the MY was observed as for a very high level of $\mathrm{U}$, over $10 \mathrm{mmol}^{-1} \mathrm{l}^{-1}$. Basically this finding was in accordance with the results of this work. It is possible to claim that B cows are more susceptible to the higher body liquids $\mathrm{U}$ in the case of their higher MY as compared with $\mathrm{H}$ animals, where this could be probably linked with their better ability to nitrogen utilize.

In the case of milk AC the higher yielding cows had significantly higher mean values (Fig. 1) for both the original data and the log transformed scale $\left(0.0499>0.0401 \mathrm{mmol} \cdot \mathrm{l}^{-1}\right.$ and $0.3224>0.14)$. It means AC $0.0362>0.0238 \mathrm{mmol} \cdot \mathrm{l}^{-1}$ in comparison of $\mathrm{xg}$. The variation coefficients were relatively similar in both groups, 81.2 and $118.5 \%$. The corresponding values in $\mathrm{H}$ cows were on the same levels, however, with opposite tendency and statistical significance in a similar situation (Janů et al. 2007). This fact suggested that B cows are probably more susceptible to the influence of MY on MIs. The milk AC is an applicable indicator of dairy cow energy metabolism state and ketosis as a productive disorder according to the mentioned authors (Andersson and Lundström 1984; Andersson 1984, 1988; Andersson and Emanuelson 1985; Gravert et al. 1986; Diekmann 1987; Jagoš et al. 1991; Gustafsson and Emanuelson 1993; Illek and Pechová 1997; Geishauser et al. 1997, 1998; Ř́ha and Hanuš 1999b; Hanuš et al. 2003). The results of this investigation were in accordance with the above mentioned knowledge, i.e. there was higher AC in the dairy cow group with more intensive energy metabolism, and therefore with higher MY. The absolute values of the found milk AC levels were not so high and could be designated as quite normal, without probability of a higher risk of the subclinical ketosis occurrence in both groups. But on the other hand, the higher intensity of the catabolism of the body fat reserves was confirmed by the results in group 1 with higher MY.

A significant effect of higher cow MY on the URN ratio was confirmed (Fig. 1). The ratio was higher in the higher yielding cows $(51.94>41.97 \%)$ and the difference was quite marked. A similar trend (46.52 > 39.09\%) was found in the $H$ cows (Janů et al. 2007). Only the difference was a little higher (approximately by $34 \%$, relatively) in the B cows ( $9.97>7.43 \%$ absolutely), which can be expected because of generally higher levels of the milk U, that were found in this breed in our investigation. The variabilities of the URN indicator were quite normal and approximately equal for all evaluations. The variation coefficients were about 34.1 and $36.0 \%$ in B and 34.5 and $42.6 \%$ in H dairy cows. These findings in both breeds are directly connected with relevant milk $U$ in the cow groups as already mentioned. The same risks for the cows usually linked with higher U and already referenced are valid in the URN ratio. A higher susceptibility of the B cows to the effect of higher MY on their lactation physiology was confirmed.

Regarding the general principles of the energy and nitrogen metabolism (Andersson 1984, 1988; Kirchgessner et al. 1985, 1986; Gravert et al. 1986; Diekmann 1987; Gustafsson and Emanuelson 1993; Hanuš et al. 1993; Illek and Pechová 1997; Pechová et al. 2000; Johnson and Young 2003; Kučera 2003) the very fact was expected that $\mathrm{F} / \mathrm{CP}$ ratio could be affected by different MYs of B cows, but in the opposite trend (1.12 \pm 0.25 versus $1.18 \pm 0.25$ ). Although the $\mathrm{MY}$ was increased, the $\mathrm{F} / \mathrm{CP}$ ratio was decreased. According to many authors the $\mathrm{F} / \mathrm{CP}$ ratio is a good indicator of energy metabolism of 

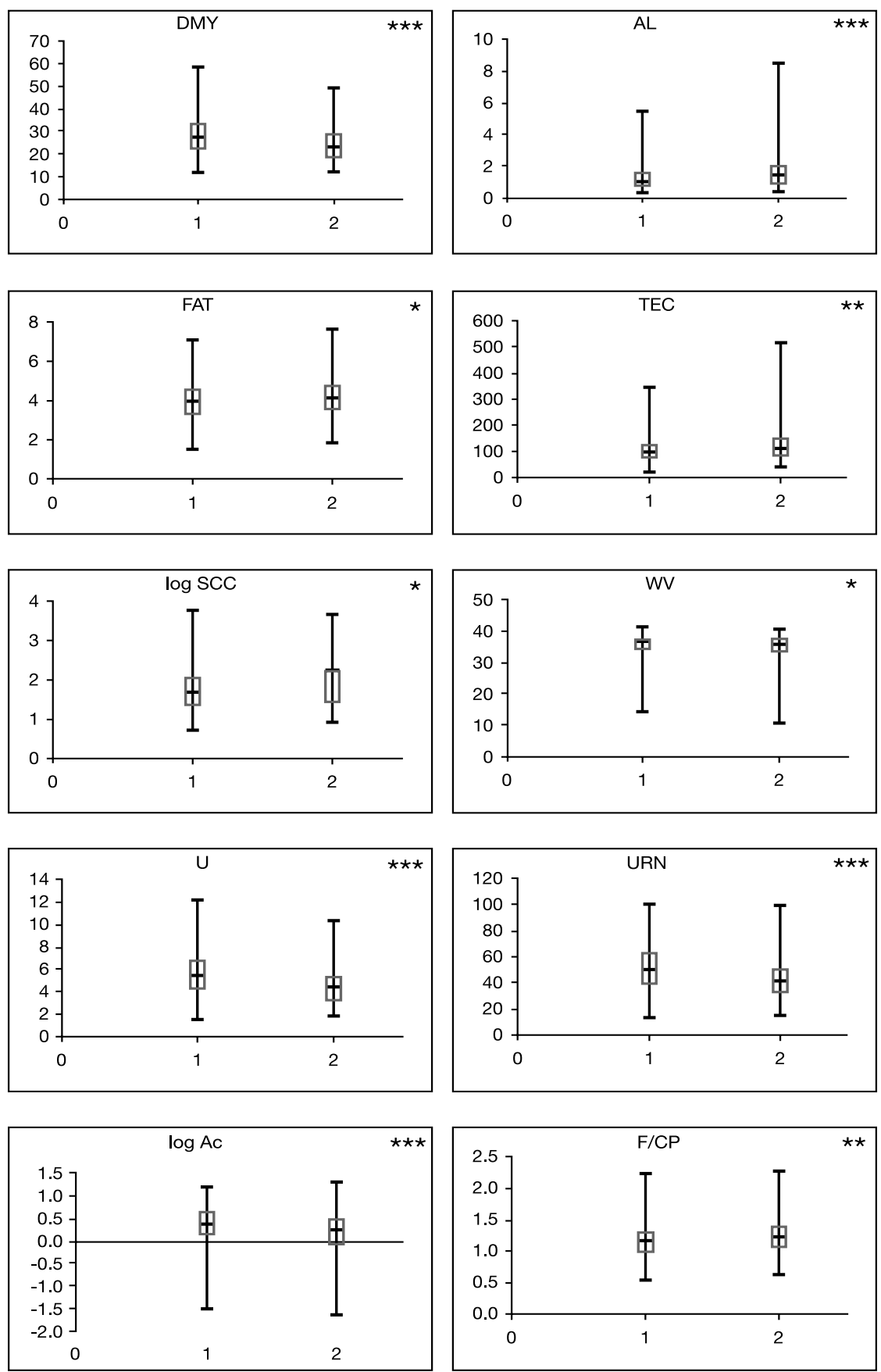

Fig. 1 Presentation of the main central statistical moments and characteristics of data frequency distribution for the cases of significant differences in the MQIs between B cows with higher (1) and lower (2) MY.

Construction of box graph: the file median (the central short horizontal line); the top edge of $1^{\text {st }}$ and $3^{\text {rd }}$ quartile (the tetragon); the variation range as difference between maximum and minimum (the vertical line). 
dairy cows and milk cheese-making ability (Agabriel et al. 1990, 1991; Bíro et al. 1992; Schulz 1997; Hanuš et al. 2003). It is known that F/CP ratio is positively well correlated $(0.33 ; P<0.001)$ with milk AC (Hanuš et al. 2004). The obtained difference (Fig. 1, F/CP) was quite low. For this reason, this change has no practical impact.

In view of the physical and technological properties of milk, the effect of MY was significant on the AL $(P<0.001)$, TCE $(P<0.01)$ and WV for cheese-making $(P<0.05$; all Table 1 and Fig. 1). It can be seen that raw milk was affected due to the higher MY of B cows in relatively important technological properties in terms of its worsening for $\mathrm{AL}$ and improvement for cheese-making. Generally expressed faster coagulation could be caused by a weaker effect of a protective factor of casein micelles, e. g. kappa-casein (its lower content), under the conditions of higher MY and consequently under certain relative energy deficiency in cows. These impacts could be important in practice in terms of raw milk processing. In $\mathrm{H}$ cows the milk technological properties were less influenced due to MY changes (Janů et al. 2007).

In conclusion, the higher MY that was reached due to an efficient breeding and a more efficient nutrition and feeding of animals, need not be the source of significantly worse raw milk quality. This holds true in case the physiological needs of dairy cows are satisfactorily met. However, here in this paper no information was evaluated about the incidental impacts of a high MY on cow pregnancy and longevity, which must not be omitted in the general evaluation of the high MY effects. These effects are described in other studies. Nevertheless, B cows are probably more susceptible to the high MY effect on their MIs than observed in $\mathrm{H}$ cows.

\section{Vlivy různé mléčné užitkovosti krav na kvalitu mléka u Českého strakatého skotu}

Mléčná užitkovost (M) je důležitým ekonomickým a zdravotním faktorem. M ovlivňuje zdravotní stav dojnic, jejich reprodukci, dlouhověkost a mléčné ukazatele (MU). Byly testovány rozdíly uvnitř MU mezi 2 stády českých strakatých dojnic $(\mathrm{C}) \mathrm{s}$ vyšší $(1 ; 8348 \mathrm{~kg}$ za laktaci; 240 individuálních vzorkủ mléka) a 2 s nižší $(2 ; 7$ 344; 239) M. Vzorkování bylo v letním a zimním krmném období. Laktační faktory byly dobře vyváženy. Skupina 1 byla na vyšší genetické úrovni, měla lepší výživu a vyšší M o 13,7 \% $(P<0,001)$. Všechna stáda byla dojena dvakrát denně. Bylo vyšetřováno 23 MU a 39,1 \% (9 z 23; 30,4 \% to bylo dříve u Holštýna $(\mathrm{H})$ při vyšší $\mathrm{M}$ o $30 \%)$ bylo ovlivněno $(P<0,05)$ relativně nižším rozdílem v M: tuk; log počtu somatických buněk; močovina (MO); aceton (AC); alkoholová stabilita; čas koagulace sýřeniny; objem syrovátky; poměr dusíku močoviny v nebílkovinném dusíku (MN); poměr obsahů tuk/bílkoviny. To vypovídá o vyšší vnímavosti dojnic $\mathrm{C}$ k vlivu vysoké dojivosti na fyziologii laktace než $\mathrm{H}$. Změny byly většinou u významnějších MU, obvykle s většími rozdíly než u H. Neovlivněno bylo celé bílkovinné spektrum $(P>0,05)$. MO byla vyšší $\left(5,707 \mathrm{mmol} \cdot 1^{-1}>4,365 \mathrm{mmol} \cdot 1^{-1}\right)$ ve skupině 1 , AC a MN také $\left(0,0362>0,0238 \mathrm{mmol} \cdot{ }^{-1}\right.$ a $\left.51,94>41,97 \%\right)$. To koresponduje s dusíkatým a energetickým metabolismem.

\section{Acknowledgements}

This study was supported by projects 1G46086 and MSM 6007665806 and by activities of the NRL-RM in Rapotín.

\section{References}

AGABRIEL C, COULON JB, MARTHY G, CHENEAU N 1990: Facteurs de variation du taux protéique du lait de vache. INRA Prod Anim 2: 137-150

AGABRIEL C, COULON JB, MARTHY G 1991: Facteurs de variations du rapport des teneurs en matiéres grasses et ptotéiques du lait de vache. INRA Prod Anim 2: 141-149 
ALI AKA, SHOOK GE 1980: An optimum transformation for somatic cells concentration in milk. J Dairy Sci 63: 487-490

ANDERSSON L 1984: Concentrations of blood and milk ketone bodies, blood isopropanol and plasma glucose in dairy cows in relation to the degree of hyperketonaemia and clinical signs. Zbl Vet Med A 31: 683-693

ANDERSSON L 1985: Subclinical ketosis in dairy cows. Veterinary Clinics of North America: Food Anim Pract 2: $233-251$

ANDERSSON L, EMANUELSON U 1985: An epidemiological study of hyperketonaemia in Swedish dairy cows: determinants and the relation to fertility. Prev Vet Med 3: 449

ANDERSSON L, LUNDSTRÖM K 1984 a: Effect of energy balance on plasma glucose and ketone bodies in blood and milk and influence of hyperketonaemia on milk production of postparturient dairy cows. Zbl Vet Med 31: 539-547

ANDERSSON L, LUNDSTRÖM K 1984 b: Milk and blood ketone bodies, blood isopropanol and plasma glucose in dairy cows, methodical studies and diurnal variations. Zbl Vet Med 31: 340-349

AYADI M, CAJA G, SUCH X, KNIGHT CH 2003: Effect of omitting one milking weekly on lactation performances and morphological udder changes in dairy cows. J Dairy Sci 86: 2352-2358

BÍRO D, LABUDA J, CABADAJOVÁ M 1992: Factors influencing cow milk production and fat to protein content ratio. (In Slovak) Živoč Výr 37: 521-528

BUCEK P, PYTLOUN P, PYTLOUN J 2004: The actual state of the cattle milk recording in the CR. (In Czech) Sborník VÚCHS Rapotín, Moderní postupy v kontrole užitkovosti skotu jako základ úspěšného šlechtění, ISBN 80-903142-3-6, p. 2-14

BUTLER WR, CALAMAN JJ, BEAM SW 1996: Plasma and milk urea nitrogen in relation to pregnancy rate in lactating dairy cattle. J Anim Sci 74: 858-865

DIEKMANN L 1987: Energiebilanz vor und nach dem Kalben. Tierzüchter 2: 72-73

FOLTYS V, KIRCHNEROVÁ K 2001: Improvement of health status in milk cows and decrease of somatic cell counts in milk by feeding the organic selenium. (In Slovak) J Farm Anim Sci XXXIV: 229-235

GEISHAUSER T, LESLIE KE, DUFFIELD T, EDGE V 1997: An evaluation of milk ketone tests for the prediction of left displaced abomasum in dairy cows. J Dairy Sci 80: 3188-3192

GEISHAUSER T, LESLIE KE, DUFFIELD T, SANDALS D, EDGE V 1998: The association between selected metabolic parameters and left abomasal displacement in dairy cows. J Vet Med A 45: 499-511

GRAVERT HO, LANGER R, DIEKMANN L, PABST K, SCHULTE-COERNE H 1986: Ketonkörper in Milch als Indikatoren für die Energiebilanz der Milchkühe. Züchtungskunde 58: 309-318

GUSTAFSSON AH, EMANUELSON U 1993: Milk acetone as indicator of hyperketonaemia in dairy cows - the critical value revised. EAAP Congress, Aarhus, Denmark 443

HANUŠ O, FOLTYS V 1991: Some characteristics and mineral components of milk of cattle breeds kept in Czechoslovakia. (In Czech) Živoč Výr 36: 497-505

HANUŠ O, GENČUROVÁ V, FICNAR J, GABRIEL B, ŽVÁČKOVÁ I 1993: The relationship of urea and protein in bulk milk to some breeding factors. Živoč Výr 38: 61-72

HANUŠ O, GAJDU゚ŠEK S, BEBER K, FICNAR J, JEDELSKÁ R 1995a: Composition and technological properties of milk from dairy cows in the middle stage of lactation and their interrelationships. (In Czech) Živoč Výr 40: 555-561

HANUŠ O, TICHÁČEK A, KOPECKÝ J 1995b: Interpretation of SCC values determined in milk samples of individual cows. (In Czech) Mliekarstvo 26: 16-19

HANUŠ O, KVAPILÍK J, KLOPČIČ M, BJELKA M 2001: Important components of nitrogen phase of milk and breeder's factors. (In Czech) In Chov a šlechtění skotu pro konkurenceschopnou výrobu: sborník referátů VÚCHS Rapotín: 114-121

HANUŠ O, FRELICH J, ROUBAL P, VORLÍČEK Z, Ř́HA J, POZDÍŠEK J, BJELKA M 2003: Dairy cow breed impacts on some chemical-compositional, physical, health and technological milk parameters. (In Czech) Výzkum v chovu skotu 45: 1-10

HANUŠ O, VYLETĚLOVÁ M, GENČUROVÁ V, BJELKA M, KOPECKÝ J, JEDELSKÁ R 2004: The importance of the raw milk laboratory testing for the dairy farmers. (In Czech) Mliekarstvo 35: 31-38

CHLÁDEK G, MÁCHAL L, VANĚK D, 2002: Blood plasma glucose and its relationship with milk production and reproduction parameters in Holstein cows. Výzkum v chovu skotu 44: 1-8

ILLEK J, PECHOVÁ A 1997: The dairy cow metabolism disorders and milk quality. (In Czech) Farmáŕ 6: 29-30

JAGOŠ P, ILLEK J, SUCHÝ P 1991: Beziehungen zwischen Störungen im Energiestoffwechsel und der Milchzusammensetzung. Mh Vet - Med 46: 698-699

JANU゚ L, HANUŠ O, FRELICH J, MACEK A, ZAJÍČKOVÁ I, GENČUROVÁ V, JEDELSKÁ R 2007: Influences of lactation physiology of Holstein high milk yielding cows on milk components and properties and milk health state markers in the Czech Republic. Acta Vet Brno: 76: 553-561

JÍLEK F, ŘEHÁK D, VOLEK J, ŠTÍPKOVÁ M, NĚMCOVÁ E, FIEDLEROVÁ M, RAJMON R, ŠVESTKOVÁ D 2006: Effect of herd, parity, stage of lactation and milk yield on urea concentration in milk. Czech J Anim Sci 51: 510-517

JOHNSON RG, YOUNG AJ 2003: The association between milk urea nitrogen and DHI production variables in vestern commercial dairy herds. J Dairy Sci 86: 3008-3015 
JUNQUEIRA FS, MADALENA FE, REIS GL 2005: Production and economic comparison of milking F-1 Holstein $\times$ Gir cows with and without the stimulus of the calf. Livestock Prod Sci 97: 241-252

KIRCHGESSNER M, KREUZER M, ROTH MAIER DORA A 1986: Milk urea and protein content to diagnose energy and protein malnutrition of dairy cows. Arch Anim Nutr 36: 192-197

KIRCHGESSNER M, ROTH MAIER DORA A, RÖHRMOSER G 1985: Harnstoffgehalt in Milch von Kühen mit Energie- bzw. Proteinmangel und anschliessender Realimentation. Z Tierphysiol Tiernähr Futterm - Kde 53: $264-270$

KIRCHNEROVÁ K, VALENT M, PETRIKOVIČ P, PAJTÁŠ M, FOLTYS V 2001: Effect of intensity and technique of feeding of precalving dairy cows on incidence of ketobodies and glycaemia after calving. (In Slovak) J Farm Anim Sci XXXIV: 123-131

KUČERA J 2003: Relationships between milk urea content, milk yield and milk composition in Holstein cows. Výzkum v chovu skotu 45: 1-6

KUČERA J, KRÁL P 2004: The Bohemian Spotted cattle breeding. (In Czech) Sborník VÚCHS Rapotín, Moderní postupy v kontrole užitkovosti skotu jako základ úspěšného šlechtění, ISBN 80-903142-3-6: 43-52

KVAPILIK J, PYTLOUN J, BUCEK P, et al. 2002, 2003, 2004: Annual Report, 2001, 2002, 2003. Cattle Breeding in the Czech Republic. (In Czech) CMSCH, a.s., Praha: 103, 110, 104

KVAPILÍK J, STŘELEČEK F 2003: Cattle and sheep quotas negotiated between the Czech Republic and the EU. Czech J Anim Sci 48: 487-498

PECHOVÁ A, ILLEK J, PAVLATA L 2000: The factors which are influencing fat concentration in cow milk. (In Czech) Veterinářství 50: 238-241

PIATKOWSKI B, VOIGT J, GIRSCHEWSKI H 1981: Einfluss des Rohproteinniveaus auf die Fruchtbarkeit und den Harnstoffgehalt in Körperflüssigkeiten bei Hochleistungskühen. Arch Tierernähr 31: 497-504

REMOND B, POMIES D, DUPONT D, CHILLIARD Y 2004: Once-a-day milking of multiparous Holstein cows throughout the entire lactation: milk yield and composition, and nutritional status. Anim Res 53, 201-212

ROPSTAD E, REFSDAL AO 1987: Herd reproductive performance related to urea concentration in bulk milk. Acta vet scand 28: $55-63$

ŘÍHA J, HANUŠ O 1999a: The relationships between pregnancy parameters of dairy cow herds and metabolical and compositional parameters in bulk milk samples. (In Czech) Výzkum v chovu skotu 41: 1-6

Ř́IHA J, HANUŠ O 1999b: The relationships between individual reproduction parameters and milk composition in first 120 lactation days. (In Czech) Výzkum v chovu skotu 41: 3-17

SAWA A, PIWCZYNSKI D 2002: Somatic cell count and milk yield and composition in White $\times$ HolsteinFriesian cows. Med Weter 28: 636-640

SHOOK GE 1982: Approaches to summarizing somatic cell count which improve interpretability. Nat. Mast. Council, Louisville, Kentucky, pp. 1-17

SCHULZ T 1997: Ohne Formeln und Tabellen die Leistung gesteigert. Top Agrar 5: 20-22

STRUSIŇSKAD, MINAKOWSKI D, PYSERA B, KALINIEWICZ J 2006: Effects of fat-protein supplementation of diets for cows in early lactation on milk yield and composition. Czech J Anim Sci 51: 196-204

SUCHÁNEK B, GAJDƯŠEK S 1991: Milk composition in the cattle breeds in the CSFR. (In Czech) Živoč Výr 36: $289-296$

SUCHÁNEK B, HANUŠ O 1997: Bulk milk sample composition in the area of one dairy factory. (In Czech) Výzkum v chovu skotu 39: 21-25

ZHAI SW, LIU JX, WU YM, YE JA, XU YN 2006: Responses of milk urea nitrogen content to dietary crude protein level and degradability in lactating Holstein dairy cows. Czech J Anim Sci 51: 518-522 
